\title{
COVID-19 Lockdown and Exposure of Households to Food Insecurity in Uganda: Insights from a National High Frequency Phone Survey
}

\author{
Peter Agamile ${ }^{1,2}$ (C)
}

Accepted: 21 December 2021 / Published online: 11 February 2022

(c) European Association of Development Research and Training Institutes (EADI) 2022

\begin{abstract}
We estimate the impact of COVID-19 lockdown induced income shocks on household food insecurity outcomes in Uganda using five rounds of a nationally representative High Frequency Phone Survey. Relative to the baseline survey conducted just before the pandemic, there was a significant decrease in households' participation in wage work, agricultural production, and non-farm business which in turn increased their income losses. Consequently, we find that lockdown induced income losses significantly increased incidences of food insecurity within households. With incidences of food insecurity increasing especially in rural areas, it is likely that COVID-19 reversed some of the gains recorded in recent years in lifting millions of rural smallholder farming households out of poverty. These results suggest that to assure the food security of poorer segments of the population especially in anticipation of future shocks, the government needs to invest more in social protection i.e., income and consumption support.
\end{abstract}

Keywords COVID-19 · Lockdown · Food insecurity · Uganda · Phone survey

\section{Résumé}

Grâce à cinq séries d'enquête à haute fréquence par téléphone, représentatives au niveau national, nous estimons l'impact qu'ont eu les chocs de revenus provoqués par le confinement lié à la COVID-19 sur l'insécurité alimentaire des ménages en Ouganda. Par rapport à l'enquête de référence menée juste avant la pandémie, il y a eu une diminution significative de la participation des ménages au travail salarié, à la production agricole et aux activités non agricoles, ce qui a accru leurs pertes de revenus. Par conséquent, nous constatons que les pertes de revenus provoquées par le

Peter Agamile

peter.agamile@manchester.ac.uk; pagamile@uw.edu

1 Daniel J. Evans School of Public Policy and Governance, University of Washington, Seattle, WA 98195, USA

2 Global Development Institute, University of Manchester, Oxford Road, Manchester M13 9PL, UK 
confinement ont considérablement augmenté les situations d'insécurité alimentaire au sein des ménages. Avec l'augmentation de l'insécurité alimentaire, en particulier dans les zones rurales, il est probable que la COVID-19 ait provoqué un recul parmi certains progrès réalisés ces dernières années pour sortir de la pauvreté des millions de ménages ruraux de petits exploitants agricoles. Ces résultats suggèrent que si l'on veut assurer la sécurité alimentaire des segments les plus pauvres de la population, en particulier en prévision de chocs futurs, le gouvernement doit investir davantage dans la protection sociale, c'est-à-dire le soutien des revenus et de la consommation.

\section{Introduction}

The initial spread of COVID-19 around the world in the first half of 2020 presented a major headache for national governments and health agencies charged with maintaining public health. As there was no known treatment or vaccine for the virus at the time many governments around the world — on the advice of health authoritiesimposed severe lockdowns, ${ }^{1}$ restricting the movement of people in attempts to slow the spread of the virus. Uganda like many other countries imposed a national lockdown. On 21 March 2020, a day before the first case of COVID-19 was reported in Uganda, the government closed all schools and shortly thereafter introduced a slew of measures including a lockdown, closure of the nation's borders (except for movement of cargo and goods) and suspension of public transport within the country.

Although credited ${ }^{2}$ with helping to slow the spread of COVID-19 in China (Yuan et al. 2020), lockdowns through their limitations of people's movements, severely disrupted economic activity in the countries in which they were implemented. For example, economic sectors such as travel and tourism, industrial manufacturing, nearly came to a halt when lockdowns were imposed (Farrell et al. 2020). In the case of Uganda, the World Bank (2021), estimated that Gross Domestic Product growth contracted by $1.1 \%$ in 2020 relative to 2019 because of the COVID-19 pandemic. A consequence of this was a massive increase in unemployment in both formal and informal sectors, exposing millions of people to large income losses. According to the International Labour Organisation (2021) projections for the Ugandan labour market, there were significant losses in working time equivalent to 1.8 million fulltime jobs in 2020 compared to 2019. Globally the International Labour Organisation estimated that the COVID-19 pandemic induced job losses led to a contraction of global labour income by a staggering 8.3\% in 2020 compared to 2019. While most workers who became redundant because of lockdowns in high-income countries received some form of income protection from their respective nations'

\footnotetext{
1 The first documented case of a full lockdown to try to stem off the spread of COVID-19 was that implemented in China in Wuhan city and other cities in the Hubei province on 23 January 2020 (Yuan et al., 2020). In the subsequent months as COVID-19 spread around the world, the Wuhan lockdown in many ways provided a blueprint for many governments who adopted lockdowns to stem off the spread of COVID-19.

2 In a multi-country analysis, Shiva and Molana (2021) actually argue that lockdowns can be ineffective in low-income countries due to absence of basic infrastructure to allow people to work remotely.
} 
governments, this was not the case in many medium- and lower-income countries. For those in the informal sectors of low-income countries with minimal job protection, the lockdowns meant instant job losses and total income loss.

Furthermore, given intra- and inter- country economic connectedness, the lockdowns also helped to amplify and transmit the impact of COVID-19 to areas with no or low infection rates as well as those areas with limited direct risk and threat to human life from the disease. This was visible in many low-income countries especially in sub-Saharan Africa as evidenced by Stoop et al. (2021) who show that people suffered substantial job losses because of lockdowns in the North Kivu province of the Democratic Republic of the Congo (DRC), a large region with a population of over 6.5 million people which had only reported 251 cases of COVID-19 by late July 2020.

While it is ex ante conceivable that all pillars of food security ${ }^{3}$ could be affected by the lockdowns (Laborde et al. 2020) our study, to a large extent, only examines food insecurity resulting from the disruption of access to food. This is on account of lockdowns having primarily induced household income losses resulting from rising unemployment and reductions in farm and non-farm revenues. These "demand side" challenges negatively affected households' access to food by reducing their purchasing power. The empirical focus on access to food is supported by Akter and Basher (2014) who showed that household income losses generally tend to increase household food insecurity. Although we do not focus so much on the "supply side" challenges which is closely associated with food availability, we recognise that the lockdown may have impacted food production through the disruption of farmers access to inputs. However, we still examine farm income losses which could be occasioned by the disruption of marketing and potentially agricultural casual labour employment opportunities. Additionally, the available data gives us richer information to analyse food insecurity from a demand than supply side because in general there is more variability in income than agricultural production at the high frequency in which the data we use was collected.

Uganda provides an interesting case to analyse the impact of the lockdowns on household food security because it had a very high and perhaps rising level of vulnerability among its population preceding the COVID-19 pandemic. First, according to the last available data for 2016, the prevalence of poverty in the country measured using the $\$ 1.90$ a day (2011 Purchasing Power Parity (PPP)) threshold and national poverty lines, stood at $41.5 \%$ and $21.4 \%$ respectively (World Bank 2020). This was a clear deterioration from four years earlier when the prevalence of poverty in the country measured using the same thresholds stood at $35.7 \%$ and $19.7 \%$ respectively. Secondly, and according to the respective last available data for 2016 and 2017, the coverage of social protection in the country stood at $2.6 \%$ of the population even

\footnotetext{
3 According to the World Food Summit (1996), "Food security exists when all people, at all times, have physical, social and economic access to sufficient, safe and nutritious food which meets their dietary needs and food preferences for an active and healthy life". From this definition, four key pillars of food security have been identified and these include availability, access, utilization and stability.
} 
though $89.4 \%$ of workers were employed informally ${ }^{4}$ (International Labour Organisation, 2020). It should be noted that the people working in the informal sector were particularly hard hit by the lockdown measures. With these levels of poverty, coverage of social protection, and the proportion of people working informally, the lockdown may have had a serious effect on the food security of millions of vulnerable people in the country.

There is now a growing body of literature such as Béné (2020), Ceballos et al. (2020), Farrell et al. (2020), Heck et al. (2020), Huss et al. (2020), Gupta et al. (2020), Zidouemba et al. (2020) Stoop et al. (2021), Mahmud and Riley (2020), Kansiime et al. (2021), Hirvonen et al. (2021) and Ruan et al. (2021) examining the impacts of COVID-19 on food systems, household income, and consumption. The general conclusion from these studies is that COVID-19 induced income losses may have led to an increase in the prevalence of food insecurity. While these studies offer useful insights, they may still have potential limitations based on their coverage and use of only one data point. Therefore, our contribution to this growing body of literature lies in presenting a new analysis that exploits nationally representative and repeated phone survey data which covers both urban and rural households. By using repeated rounds of data collection, we provide new insights that help to expand our understanding of how households fared throughout the course of the lockdown. This knowledge has potential future policy applications especially in deciding when and for how long appropriate public interventions should be applied to assure the welfare of vulnerable populations after exposure to shocks.

Even though the full health, socioeconomic, and other impacts of the COVID19 pandemic may take several years to understand since the pandemic is far from over, this paper aims to provide initial insights that can be used to inform ongoing policy responses to the pandemic and to be a basis for deeper analysis. Our specific objective is to estimate the impact of COVID-19 lockdown induced income shocks on household food security outcomes. The rest of the paper is structured as follows. In Sect. 2, we describe our data and present some descriptive statistics. In Sect. 3, we briefly present the estimation strategy. Thereafter, our regression results are presented in Sect. 4. Section 5 concludes the paper.

\section{Data and Descriptive Statistics}

\section{Data and Sample Characteristics}

Although the lockdown disrupted traditional ways of data collection such as face-toface interaction between survey respondents and interviewers (Rahman et al. 2021), the World Bank together with Uganda Bureau of Statistics (UBOS) were able to leverage the existent Living Standards Measurement Study (LSMS) infrastructure and framework in Uganda to conduct High Frequency Phone Surveys (HFPS) at monthly

\footnotetext{
4 This is the proportion of the population engaged in informal employment as a percentage of total employment, and it is computed from the National Labour Forces Survey.
} 
Table 1 Sample characteristics

\begin{tabular}{|c|c|c|c|c|c|c|c|}
\hline & \multirow{2}{*}{$\begin{array}{l}\text { UNPS } \\
\text { 2019/20 } \\
\text { baseline }\end{array}$} & \multicolumn{6}{|l|}{ HFPS } \\
\hline & & $\begin{array}{l}\text { Round } \\
1 \text { (Jun } \\
2020 \text { ) }\end{array}$ & $\begin{array}{l}\text { Round } \\
2 \text { (Jul } \\
2020)\end{array}$ & $\begin{array}{l}\text { Round } \\
3 \text { (Sep } \\
2020)\end{array}$ & $\begin{array}{l}\text { Round } \\
4 \text { (Oct } \\
2020)\end{array}$ & $\begin{array}{l}\text { Round } \\
5 \text { (Feb } \\
2021)\end{array}$ & Overall \\
\hline $\begin{array}{l}\text { Number of house- } \\
\text { holds }\end{array}$ & 3077 & 2227 & 2199 & 2147 & 2136 & 2121 & 10830 \\
\hline Household size & 5.076 & 5.171 & 5.397 & 5.387 & 5.412 & 5.463 & 5.366 \\
\hline \# children/ household & 2.619 & 2.823 & 3.012 & 3.005 & 3.000 & 3.050 & 2.978 \\
\hline \multicolumn{8}{|l|}{$\begin{array}{l}\text { Household head } \\
\text { gender }\end{array}$} \\
\hline Female & 1096 & 694 & 691 & 679 & 677 & 670 & 3411 \\
\hline Male & 1981 & 1527 & 1505 & 1466 & 1454 & 1451 & 7403 \\
\hline \multicolumn{8}{|l|}{ Location } \\
\hline Rural & 0.735 & 0.735 & 0.744 & 0.745 & 0.743 & 0.744 & 0.742 \\
\hline Urban & 0.242 & 0.265 & 0.256 & 0.255 & 0.257 & 0.256 & 0.258 \\
\hline \multicolumn{8}{|l|}{ Regional distribution } \\
\hline Central & 0.254 & 0.268 & 0.257 & 0.259 & 0.259 & 0.258 & 0.260 \\
\hline Eastern & 0.228 & 0.246 & 0.251 & 0.246 & 0.250 & 0.247 & 0.248 \\
\hline Northern & 0.280 & 0.235 & 0.238 & 0.241 & 0.240 & 0.241 & 0.239 \\
\hline Western & 0.237 & 0.251 & 0.254 & 0.254 & 0.252 & 0.254 & 0.253 \\
\hline
\end{tabular}

Source Based on Authors calculations (HFPS Round 1, 2, 3, 4 and 5 and UNPS 2019/2020)

intervals (Uganda Bureau of Statistics 2020) to understand the impact of COVID-19 on household welfare. The sample in the HFPS was selected from households in the 2019/2020 Uganda National Panel Survey (UNPS) which had a phone number for at least a household member or one reference individual. The data collection started in June 2020, and we used five rounds of the survey collected up to February 2021. ${ }^{5}$ Like the standard UNPS, the coverage of the phone survey was national, and included both rural and urban areas. To compute the magnitude of changes in household participation in key occupations and income before and during the lockdown, we matched the HFPS to the baseline 2019/2020 UNPS.

The key variables we selected from the data included different household occupations (wage work, agricultural production, and non-farm business) and changes i.e., an increase, no change, reduction, and total loss in household income from the different occupations. To measure food insecurity, we use the range of indicators: 1. Eat non healthy food; 2. Eat fewer kinds of food; 4. Eat less, 5. No food stock; 6. Nothing to eat; 7. Have no food for a whole day and 8. Skip meal. According to Maxwell (1996), the frequency and intensity of these different coping strategies measure the short-term food insecurity of households. An important point to note

\footnotetext{
5 The data is available from the World Bank and can be accessed from here https://microdata.worldbank. org/index.php/catalog/3765.
} 
Table 2 Differences in household occupation and income before and during lockdown

\begin{tabular}{llllll}
\hline Variable & All & HFPS sample & $\begin{array}{l}\text { UNPS 2019/2020 } \\
\text { selected sample }\end{array}$ & Difference & SE \\
\hline $\begin{array}{l}\text { Occupation } \\
\text { Wage work }\end{array}$ & 0.177 & 0.122 & 0.415 & $-0.293^{* * *}$ & $(0.009)$ \\
Agricultural production & 0.672 & 0.667 & 0.691 & $-0.024^{*}$ & $(0.011)$ \\
$\quad$ Non-farm business & 0.235 & 0.204 & 0.368 & $-0.164^{* * *}$ & $(0.010)$ \\
Income reduction & & & & $0.058^{* * *}$ & $(0.008)$ \\
$\quad$ Wage work & 0.135 & 0.145 & 0.087 & $0.096^{* * *}$ & $(0.011)$ \\
$\quad$ Agricultural production & 0.314 & 0.33 & 0.234 & $0.253^{* * *}$ & $(0.009)$ \\
Non-farm business & 0.225 & 0.268 & 0.015 & & \\
Observations & 13,049 & & & & \\
\hline
\end{tabular}

Source: Based on Authors calculations (HFPS Round 1, 2, 3, 4 \& 5 and UNPS 2019/2020)

here is that the food insecurity indicators surveyed in the HFPS were not tracked in the 2019/2020 UNPS.

Table 1 summarises the characteristics of our sample. The sample had 2,227 households selected out of the 3077 households in the 2019/2020 UNPS that were interviewed right before the arrival of COVID-19 in Uganda. The selected households were interviewed repeatedly during the lockdown in five rounds giving us 10,830 observations with a few households missing in the second, third, fourth and fifth rounds. On average the household size in the sample was 5.366 people including 2.978 children. Unlike the traditional panel household surveys that are usually conducted on an annual basis - and thereby possess greater variation in household size and number of children per household - this was not the case in the phone surveys which were conducted on short monthly intervals. The number of males who head households was more than twice that of females. Whereas the sample was almost evenly distributed across the four regions of the country, most of the households were in rural areas. The bigger percentage of rural households in the sample somewhat reflects the general settlement pattern in the country with over $75 \%$ of the total population of the country living in rural areas as of 2019 (World Bank 2020). A full list of the variables used in our analysis and their respective definitions is presented in the Appendix in Table 11.

\section{Descriptive Statistics}

Table 2 summarises changes in household occupation and income before and during the lockdown. The results show that there was a significant reduction in household participation in all three occupations tracked during the lockdown relative to before the lockdown. The largest decline in work participation during lockdown relative to the period before was recorded in wage work at $29.3 \%$. This could be attributed to the severe movement restrictions that denied workers the opportunity to travel to their usual work locations. While in many other countries, most people switched to virtual work, this was largely not possible in Uganda due to constraints such as low 
Table 3 Differences in household occupation and income between selected and non-selected baseline sample for the HFPS

\begin{tabular}{llllll}
\hline Variable & All & $\begin{array}{l}\text { UNPS 2019/2020 } \\
\text { non selected sample }\end{array}$ & $\begin{array}{l}\text { UNPS 2019/2020 } \\
\text { selected sample }\end{array}$ & Difference & SE \\
\hline $\begin{array}{l}\text { Occupation } \\
\quad \text { Wage work }\end{array}$ & 0.407 & 0.387 & & & \\
$\quad$ Agricultural production & 0.69 & 0.687 & 0.415 & -0.029 & $(0.020)$ \\
$\quad$ Non-farm business & 0.341 & 0.27 & 0.691 & -0.004 & $(0.019)$ \\
Income reduction & & & 0.368 & $-0.099 * * *$ & $(0.019)$ \\
$\quad$ Wage work & 0.089 & 0.095 & 0.087 & 0.008 & $(0.012)$ \\
$\quad$ Agricultural production & 0.238 & 0.247 & 0.234 & 0.013 & $(0.017)$ \\
$\quad$ Non-farm business & 0.014 & 0.011 & 0.015 & -0.005 & $(0.005)$ \\
Observations & 3077 & & & & \\
\hline
\end{tabular}

Source: Based on Authors calculations (UNPS 2019/2020)

internet connectivity and the fact that most businesses and offices still do not have the set up to operate online. As expected, there was minimal decline in the proportion of household engaged in farm work compared to the waged work and non-farm business. This is because, overall, the lockdown conditions did not prevent farmers from going to work on their farms. In terms of income reduction, the largest losses were recorded in non-farm business. This could be attributed to the informal nature of these businesses meaning they did not have any external support mechanisms such as insurance to mitigate their losses. While the government did announce a stimulus package to provide credit lines to help businesses recover from the pandemic induced losses, it is unlikely that most of the small and often informal businesses accessed this money. This is because the largest chunk of the stimulus package, $93 \%$ was channelled through mainly two entities; Uganda Development Bank (UDB) and Uganda Development Corporation (UDC) and just 7\% left to be channelled through the Microfinance Support Centre (MSC) (Initiatives for Social and Economic Rights 2021). As UDB and UDC generally tend to lend to large formal businesses, it means the small informal businesses did not get much relief since their main source, the MSC got a very small share of the government's stimulus package for onward delivery. The modest income losses recorded for wage work could be attributed to the fact that most employers due to contractual obligations likely continued to pay their employees even during the lockdown. Table 3 summarises differences in household occupation and income between households that were selected and non-selected from the baseline sample for the HFPS. Other than participation in non-farm business, there was no significant difference between households that were selected and those not selected.

Table 4 presents key summary statistics on household occupations, changes in income, and food insecurity outcomes. The first five columns present the results by round of data collection, whilst the sixth column presents the pooled results. The results show that the proportion of households engaged in waged work declined from $14.7 \%$ in the first round to $9.6 \%$ in the second round. After the second round, 


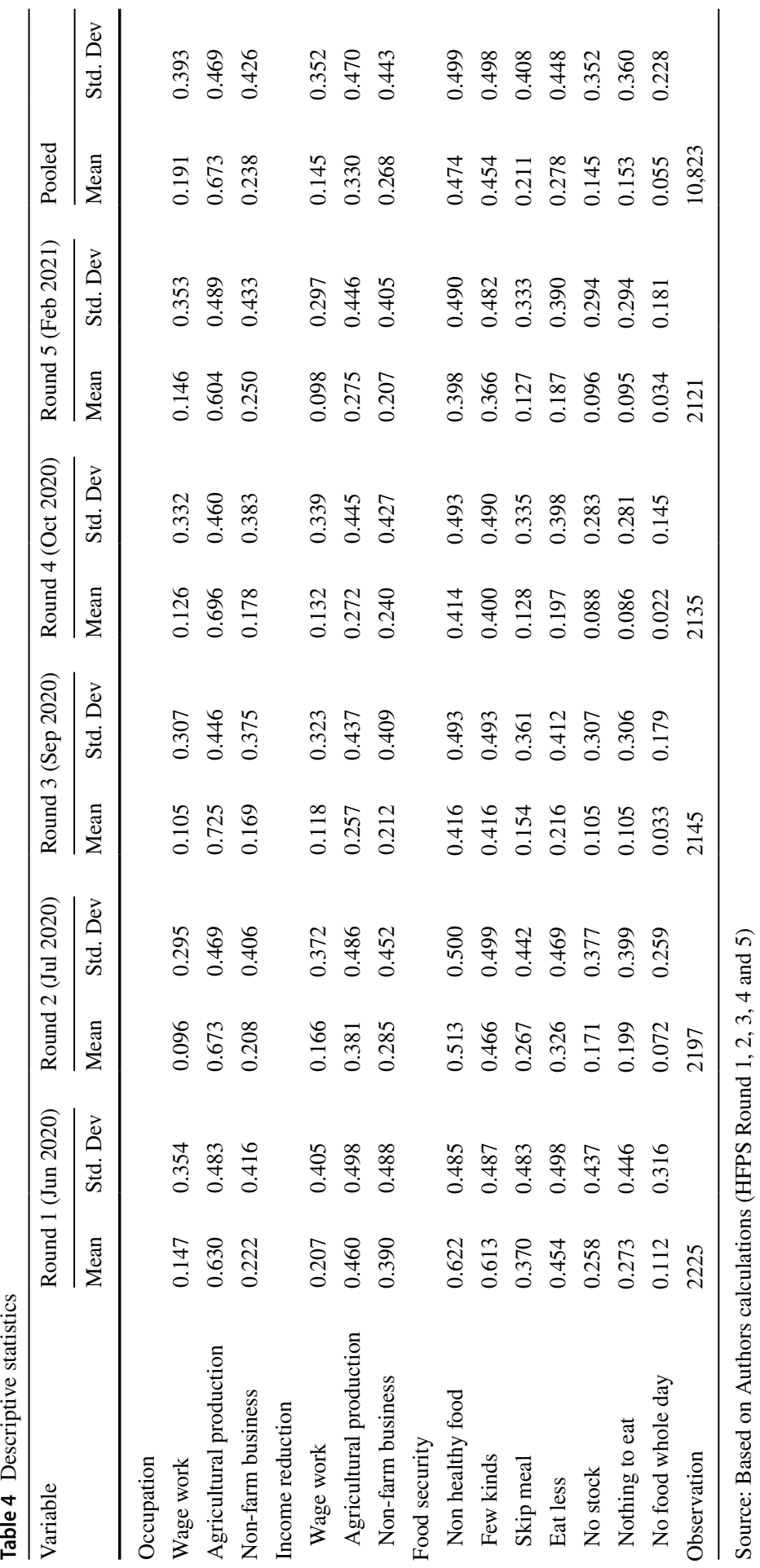


the proportion of households engaged in waged work rose continuously up to the fifth round. The initial low proportion of household engaged in waged work and the eventual rise of the same, can be attributed to the severe restrictions on people's movement at the onset of the lockdown which was thence relaxed some months later; thereby enabling an upsurge in waged work. On average, $67.3 \%$ of households engaged in agricultural production, marking it as the single largest occupational activity within households. This is somewhat expected given that $74.2 \%$ of the households in the sample are in rural areas (see Table 1) and agriculture tends to be the main livelihood activity there. The notable increase in the proportion of households engaged in agricultural production from $63 \%$ in round one to $72.5 \%$ in round three before declining to $60.4 \%$ in round five can be attributed to agricultural seasonal cycle in the country. Basically, the initial increase coincides with the second agricultural season which peaks around September (round three) and the decline thereafter coincides with harvest season and long dry season between season two in 2020 and season one in 2021. During the harvest period and dry spell between the two seasons highlighted above, agricultural labour requirements generally tend to be minimal. While there is a stronger seasonal element driving the trends in the number of households engaged in agriculture, it is also possible that the disruption of economic activity in urban areas may have pushed some people to relocate to rural areas and join the farming ranks. The damaging effects of the lockdowns with regards to agricultural production was primarily in limiting post farmgate activities such as transporting, processing, and marketing of farm produce thereby affecting farmers income. Accordingly, on average, households reported the largest income losses in agricultural production (33\%) followed by non-farm business $(26.8 \%)$, wage work (14.5\%). The slightly lower reduction in waged work income could be attributed to the fact that waged work usually carries contractual obligations ${ }^{6}$ on the part of the employer meaning most employees likely continued to receive wages. Even though the geographic coverage of the studies of Mahmud and Riley (2020) and Kansiime et al. (2021) was limited, our results support their findings that showed a significant reduction in non-farm, labour dependent income loss following the imposition of the lockdown. In terms of food insecurity, on average between 45 to $48 \%$ of households reported eating non healthy and fewer kinds of food, between 21 to $28 \%$ reported skipping a meal or eating less, and between 5 to $16 \%$ had no stock, nothing to eat and no food for a whole day. Additional summary statistics showing household food security status by the different income losses they suffered i.e., farm, non-farm business, wage and remittance income loss are presented in the Appendix in Tables 12, $13,14$.

\footnotetext{
${ }^{6}$ In principle these contractual obligations are enshrined in the local labour laws. However, in the exceptional circumstances created by the COVID-19 pandemic, it is also likely that these provisions were not implemented uniformly for all the workers in the different sectors.
} 


\section{Empirical Approach}

We estimated the impact of COVID-19 induced income loss on households' food security outcomes using a Probit model. The choice of a Probit model was informed by the nature of our dependent food insecurity variables which are categorical. Peele et al. (1998) show, empirically, that when the dependent variable is categorical, a Probit model is a better choice. Additionally, we also estimated the impact of income loss on households' food security outcomes using Ordinary Least Squares (OLS) estimation. While OLS is typically not the preferred choice when the dependent variables are categorical, Noreen (1988) empirically showed that OLS can still perform as well as a Probit. The regression equation we estimated can be written as below.

$$
y_{i j t}=\alpha+\beta_{1} e_{j t}+\beta_{2} x_{j t}+\beta_{3} d_{j t}+r_{t}+w_{t}+\varepsilon_{j t}
$$

where $y$ is the incidence of a range of food seurity indicators $i$ (with $i=$ eat non healthy food, few kinds of food, skip meal, eat less, no stock, nothing to eat and no food for a whole day) in a household $j$ at time $t$ (with $t=$ June, July, September, and October 2020, and February 2021). The different food security indicators are binary variables which take the value one if a household reports using them and zero otherwise. $e$ is a vector of variables which capture the main household occupations, and these include wage work, agricultural production, and non-farm business. The variables were defined as dummies which took the value one if a household engaged in that occupation and zero otherwise. $x$ is a vector of income loss shocks such as loss of farm, non-farm business, wage, and remittance income. The variables were defined as dummies which took the value one if a household experienced income loss from that income source and zero otherwise. $d$ is a vector of different household head and household characteristics such as age, gender, household size and number of children in the household. $r$ and $w$ are region and round/wave specific fixed effects. $\varepsilon$ is the error term.

\section{Results and Discussion}

\section{Incidence of Food Insecurity}

Tables 5 and 6 respectively summarise the results of the Probit and OLS parameter estimates. The dependent variable in each of the estimations is the specific food insecurity indicator as listed in the column head. Consistent with expectations, engagement in either waged or farm work significantly reduced incidences of food insecurity among households. Both the Probit and OLS estimation results show that lockdown induced reductions in household income from the major income sources significantly increased incidences of food insecurity among households. The Probit estimation results in Table 5 show that, a reduction in wage income significantly increased incidences of households' eating less (41.4\%), non-healthy (43.7\%) and fewer kinds (49\%) of food. Additionally, it also significantly increased incidences of households' skipping a meal (40.4\%), having no food for a whole day (15\%), having 


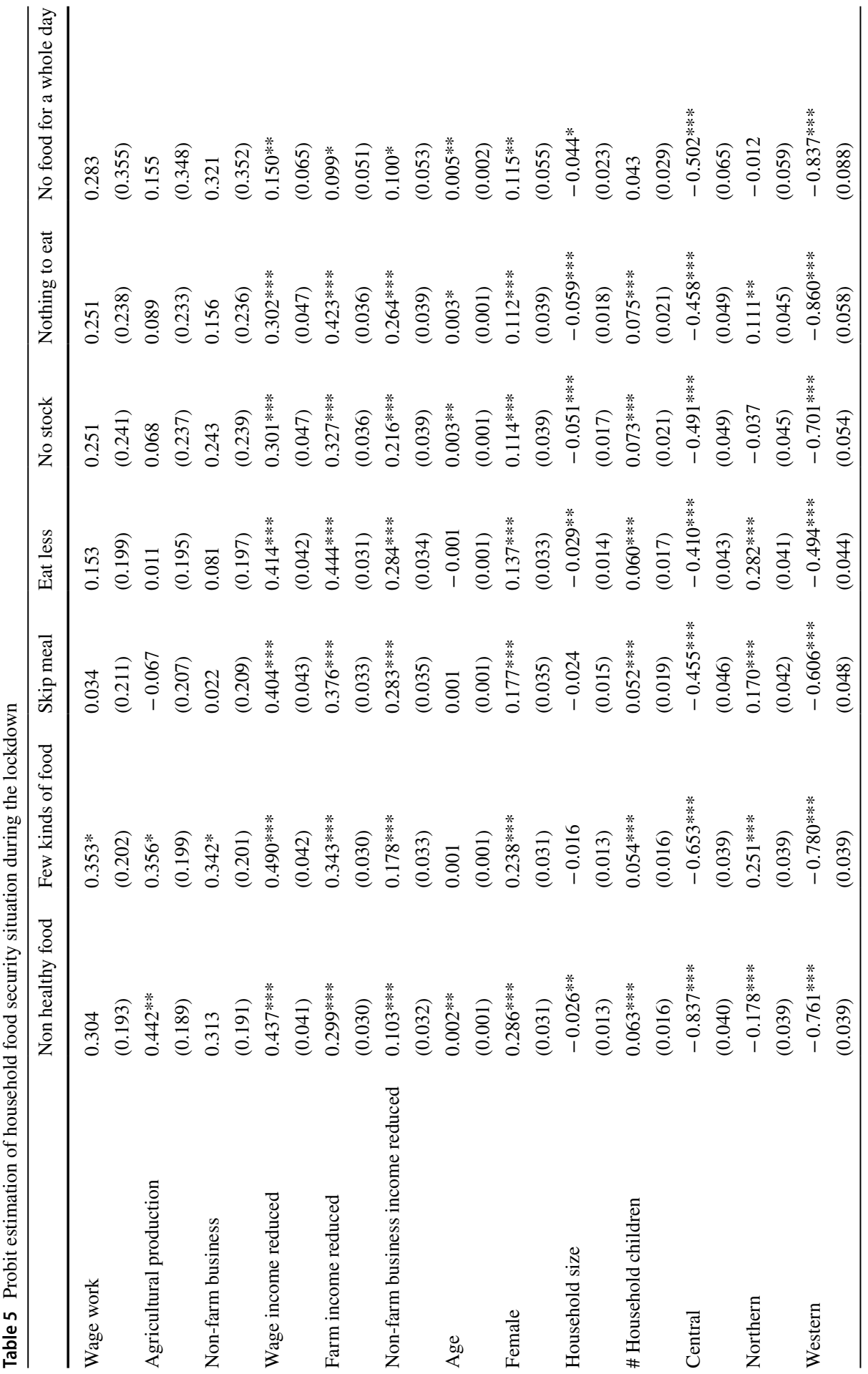

站。 


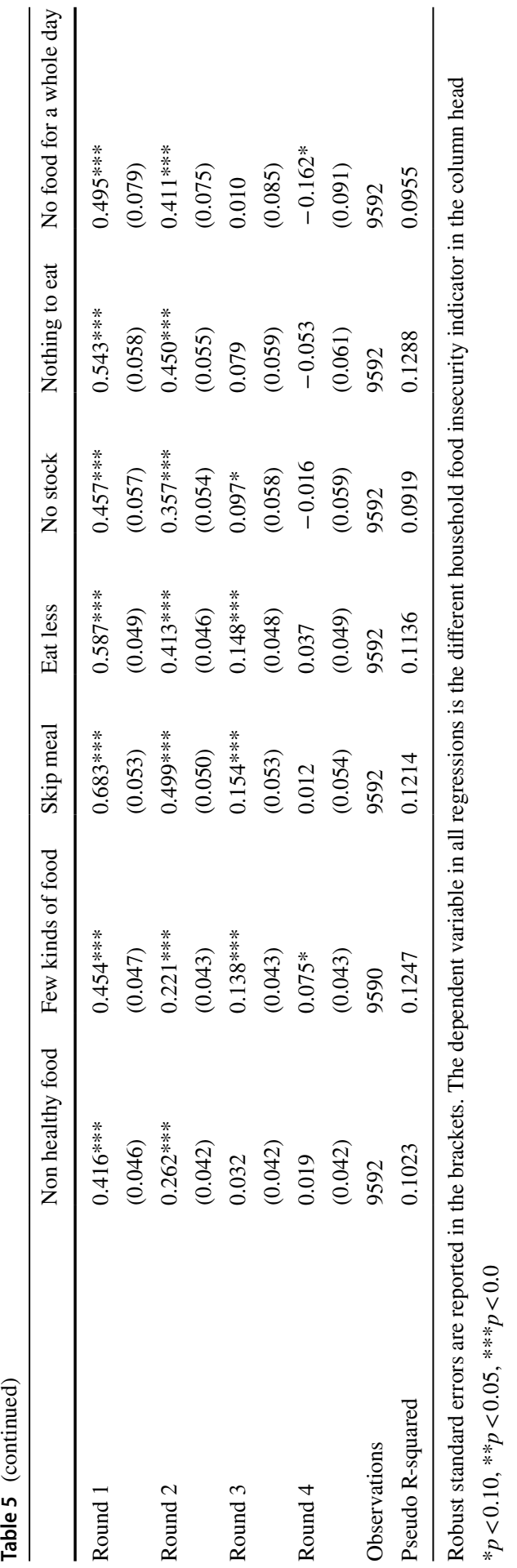




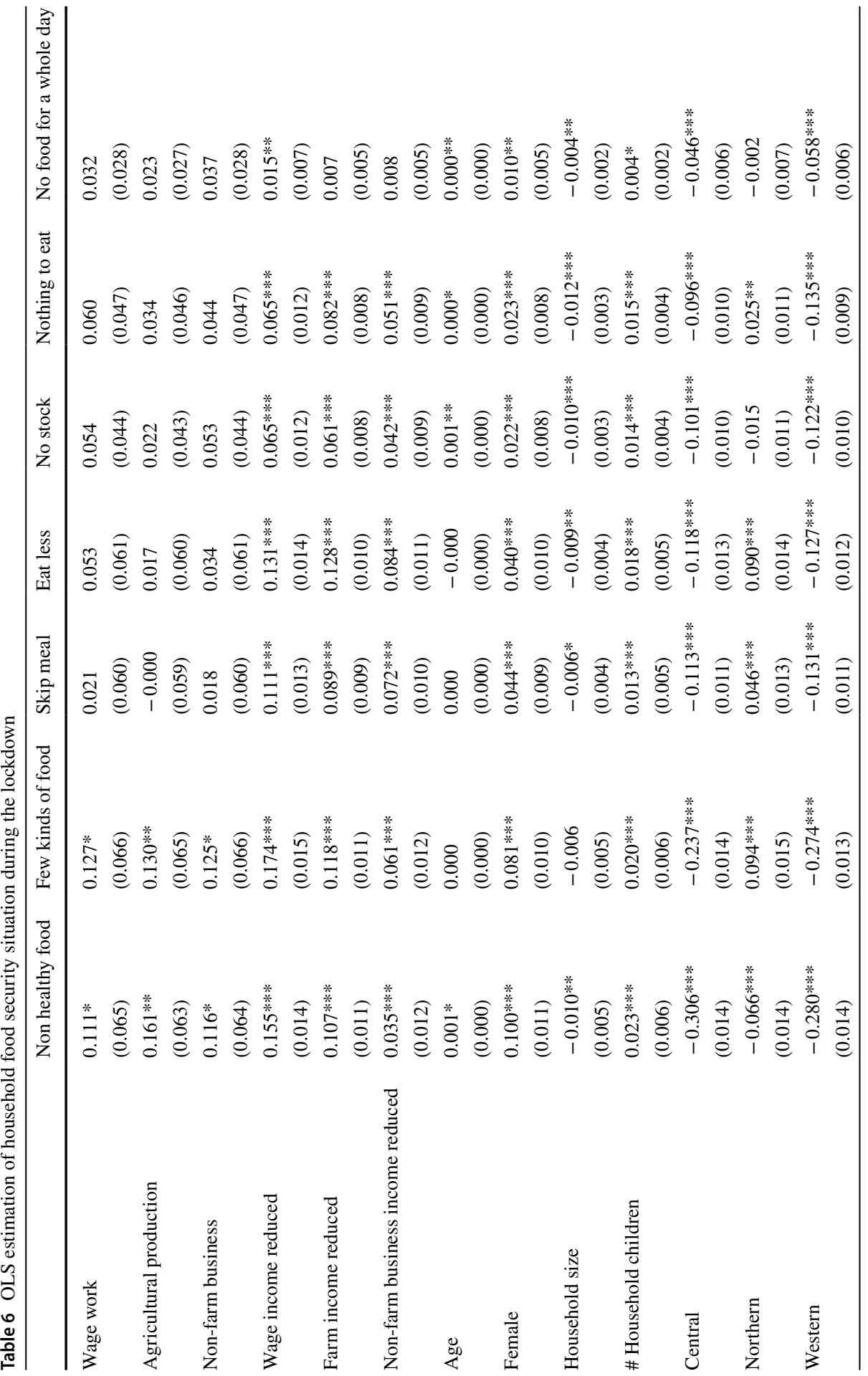

站。 


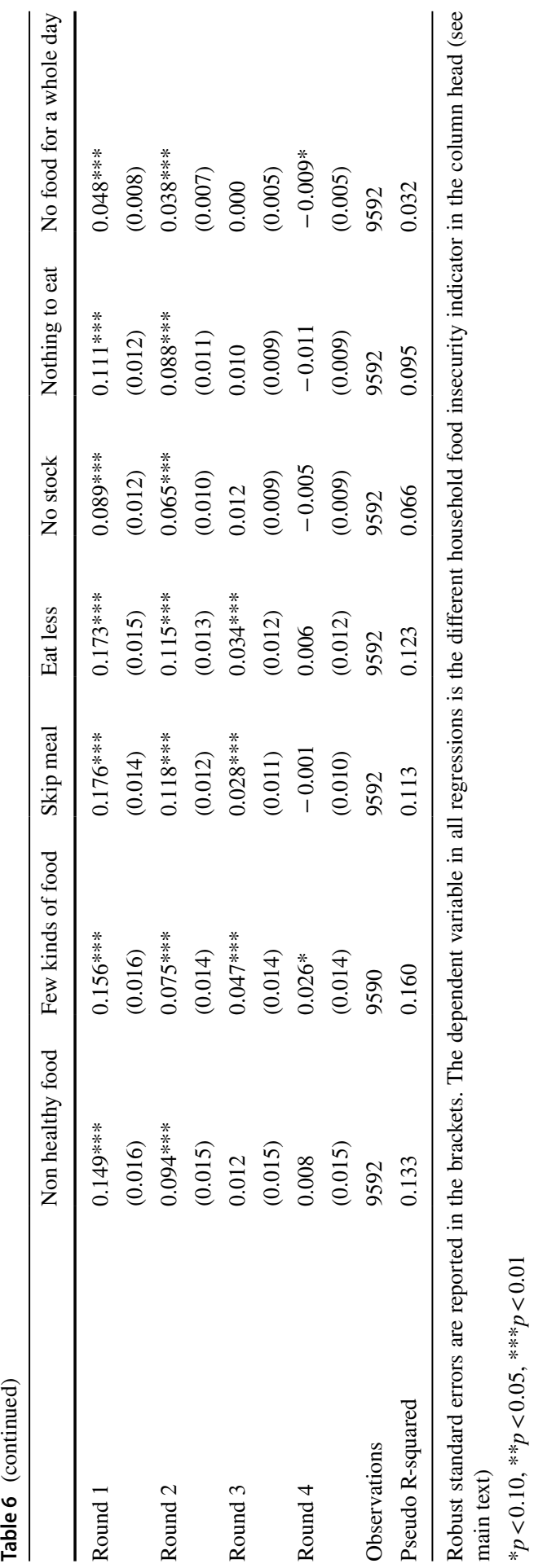


nothing to eat $(30.2 \%)$ and possession of no stock (30.1\%). Similarly, a reduction in farm income significantly increased incidences of households' eating less (44.4\%), non-healthy $(29.9 \%)$ fewer kinds $(34.3 \%)$ of food, skipping a meal (37.6\%), having no food for a whole day (9.9\%), having nothing to eat $(42.3 \%)$ and possession of no stock $(32.7 \%)$. While the increase in incidences of food insecurity following the reduction of farm income may appear to be counterintuitive on account of the general expectation that agricultural households typically rely on home produced food to assure their food security, we advance two possible explanations for this. First, as Simler (2010) shows, poor households in Uganda including those in rural areas who primarily practice agriculture tend to be net buyers of staple foods meaning they do not produce all the different kinds of food they require for consumption and thus must rely on markets for some items. Therefore, any reduction in farm income would increase the prevalence of food insecurity amongst them. Secondly, with the lockdown having severely disrupted movement, it is likely that two mutually reinforcing forces may have come into play further driving food insecurity. On one hand, farmers fearful of limited market opportunities scaled back production, which in turn reduced their income. On the other hand, markets fearing reduction in supply hiked food prices. Therefore, farmers with reduced income in a market with high food prices were bound to experience an increased prevalence of food insecurity.

Relatedly, non-farm business income loss also significantly increased incidences of households' eating less and fewer kinds of food in addition to skipping meals, the magnitude of the increase was much less compared to that which resulted from wage and household agricultural income reduction. This could be because non-farm business is secondary for most households. The main explanation for the increase in incidences of household food insecurity was the reduction in the purchasing power of households to access food due to loss of income. The additional shock of continuous increase in food prices especially during the lockdown from May to December 2020 (FAO 2021), may partly explain the large and drastic increase in the incidences of food insecurity within households.

The results for the other explanatory variables were also consistent with our expectations. For example, a greater number of children in a household increased incidences of food insecurity. In terms of regional incidences of food insecurity, the results showed that unlike the central and western regions of the country, there was a significant increase in incidences of food insecurity among households in northern Uganda. This trend can be explained by two factors. First, in Kampala and neighbouring districts in the central region, the government provided emergency relief food $^{7}$ to the poor (Isabirye and Musasizi 2020) following the start of the lockdown thereby drastically helping to assure the food security of the most vulnerable. Secondly, and consistent with the particularly low prevalence of poverty in western Uganda compared to other regions (Uganda Bureau of Statistics 2019), the lockdown did not have such a damaging impact on the food security of households in the region compared to other regions. The round dummies also showed that the magnitude of incidence of food insecurity was higher in the first round than in the later

\footnotetext{
7 The relief food package included $6 \mathrm{kgs}$ of maize flour and $3 \mathrm{kgs}$ of beans per person and salt (with supplements of $2 \mathrm{kgs}$ each of powdered milk and sugar provided to lactating mothers and the sick).
} 
rounds. This could be attributed to the fact that government gradually relaxed the lockdown rules allowing people to resume some of their livelihood activities thereby improving their food security outcomes.

In general, the results in Table 5 continue to hold in the OLS estimation in Table 6 although the coefficients are quantitatively smaller. Specifically, a reduction in wage income significantly increased incidences of households eating less (13.1\%), nonhealthy $(15.5 \%)$ and fewer kinds $(17.4 \%)$ of food. It also significantly increased incidences of households skipping a meal (11.1\%), having nothing to eat $(6.5 \%)$ and possession of no stock $(6.5 \%)$. On the other hand, reduction in farm income also significantly increased the incidences of households eating less (12.8\%), non-healthy (10.7\%) and fewer kinds (11.8\%) of food, skipping a meal (8.9\%), having nothing to eat $(8.2 \%)$ and possession of no stock $(6.1 \%)$. The same trend in incidences of food insecurity due to reduction in wage and farm income was also recorded for non-farm income reduction.

\section{Incidence of Household Food Insecurity in Rural and Urban Areas}

To examine the impact of the lockdowns on the food security status of rural and urban households, we re-estimated Eq. (1) and restricted the sample in each case to either rural or urban households. Tables 7 and 8 summarise the results of the Probit parameter estimates and 9 and 10 summarise the results of the OLS parameter estimates with samples in each case restricted to either rural or urban households, respectively. While the results show that there was a significant increase in incidences of food insecurity across both rural and urban areas, there are still notable differences between the two locations especially in terms of the magnitude of incidences of food insecurity. As expected, the loss of farm income had a significantly bigger impact on incidences of food insecurity in rural than urban areas. For example, whereas loss of farm income significantly increased incidences of households that ate fewer kinds of food, skipped a meal, or ate less by $40.8 \%, 45.3 \%$, and $53 \%$ respectively (Table 7), the corresponding increase in urban areas $(15.9 \%, 19.9 \%$ and $23.7 \%$ ) (Table 8) was about half or less than that of the rural areas. This differential between rural and urban areas could be attributed to the fact that unlike the later that tend to have multiple income sources, the former largely rely on sole farm income. Therefore, any shocks to farm income would expose them to more food insecurity relative to urban dwellers with multiple income sources including even urban farming. Maxwell (1995) already documented that especially in the urban settings of Kampala, many households engaged in urban farming to diversify their income sources. Similar findings of engagement in urban farming to diversify household income sources were reported by Foeken and Owuor (2008) and Mkwambisi et al. (2011) in their analysis of the urban poor across selected cities in Kenya and Malawi, respectively. On the other hand, non-farm business income reduction increased incidence of food insecurity within households in urban more than in rural areas as evidenced by the respective significant positive coefficients. This could be attributed to the generally high ownership of non-farm business by people in urban areas compared to their counterparts in rural areas. Nagler and Naude (2014) explain that rural households essentially engage in non-farm business as a secondary measure to help 


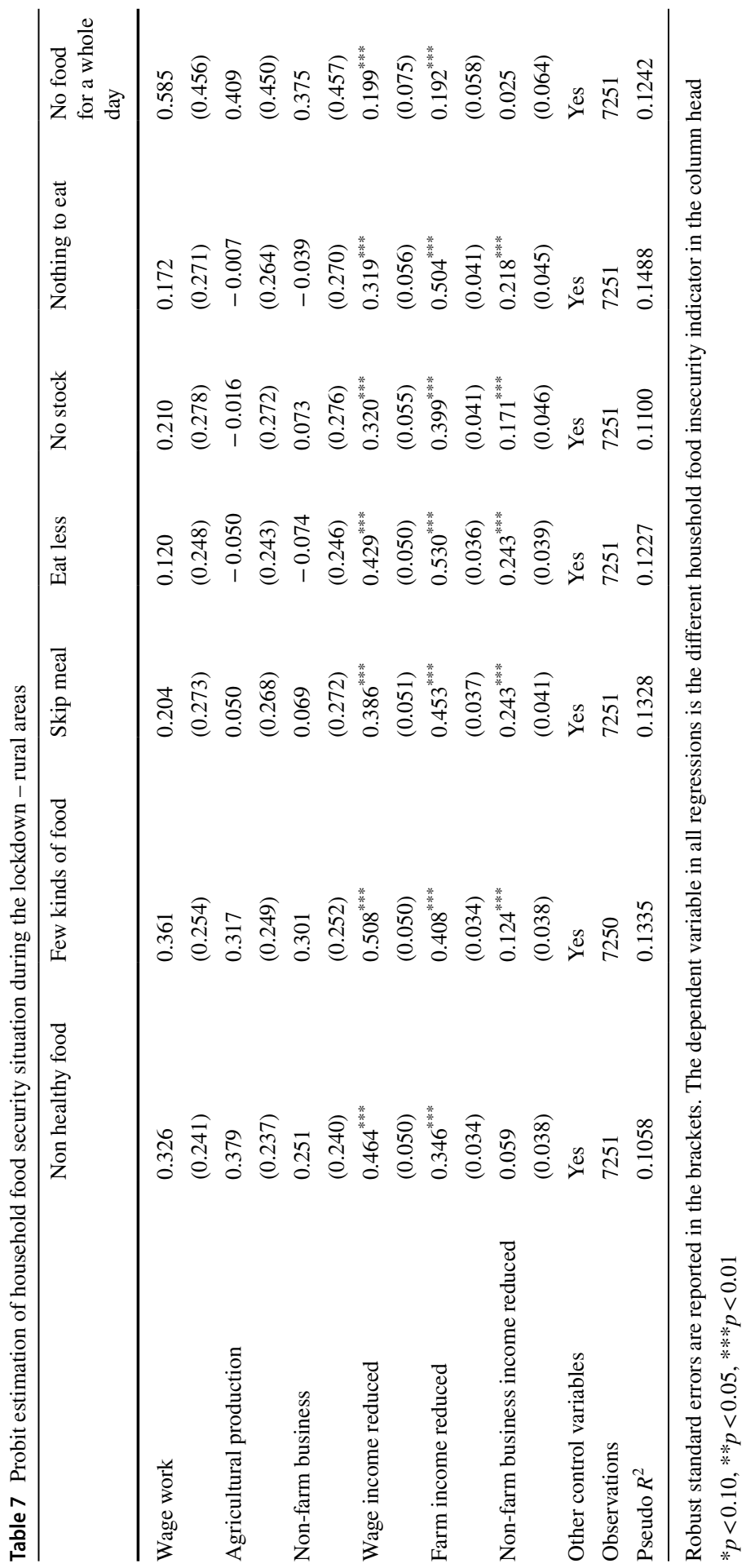




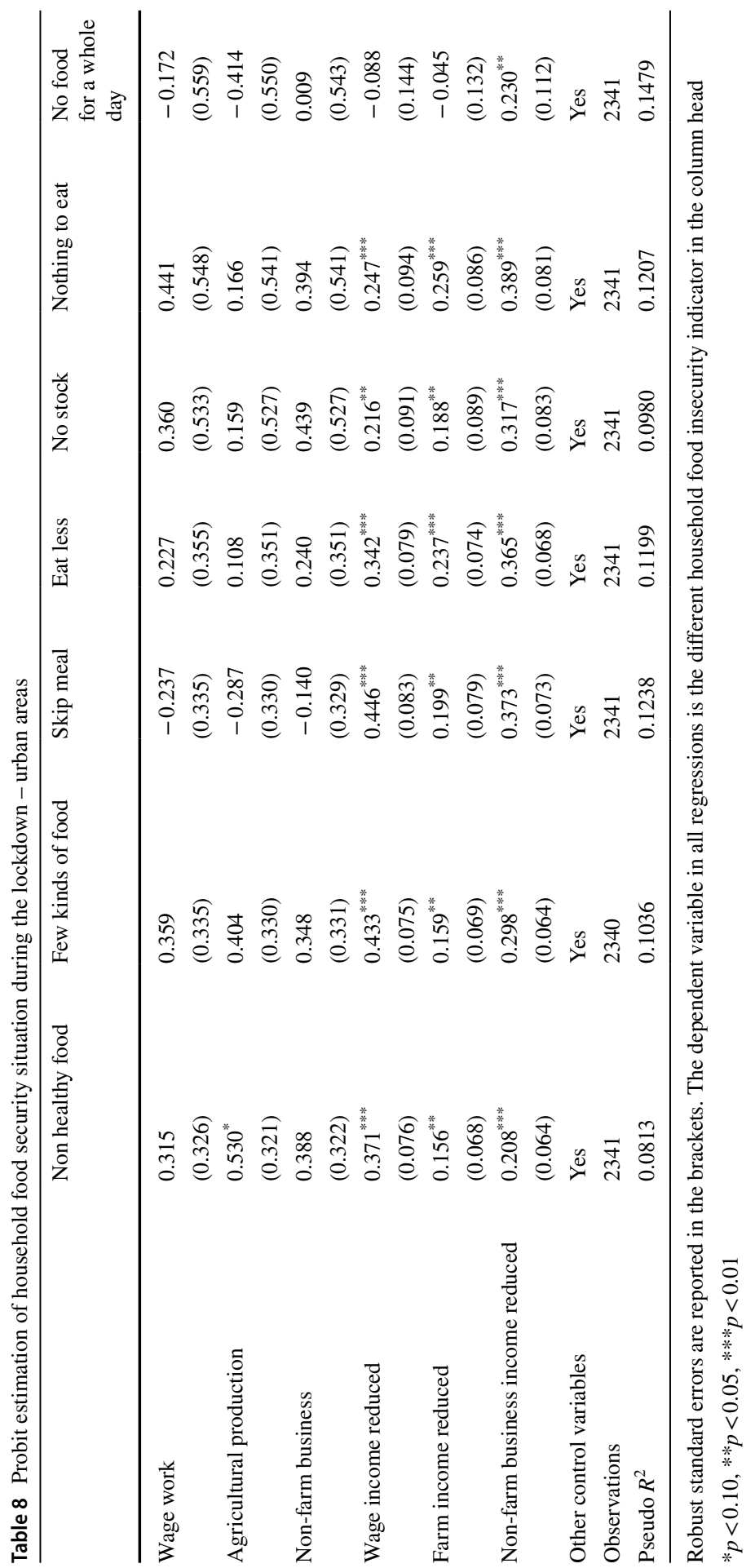




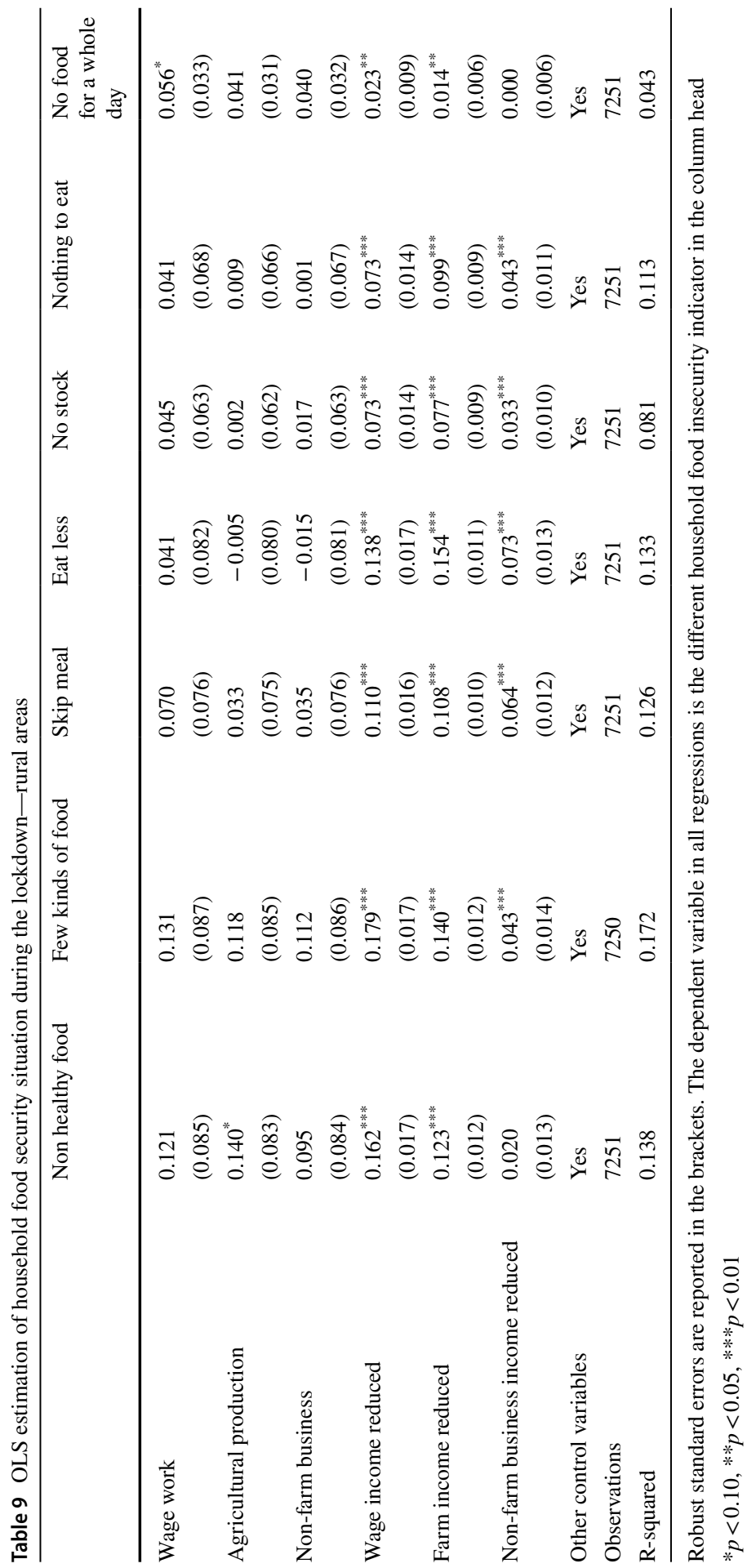




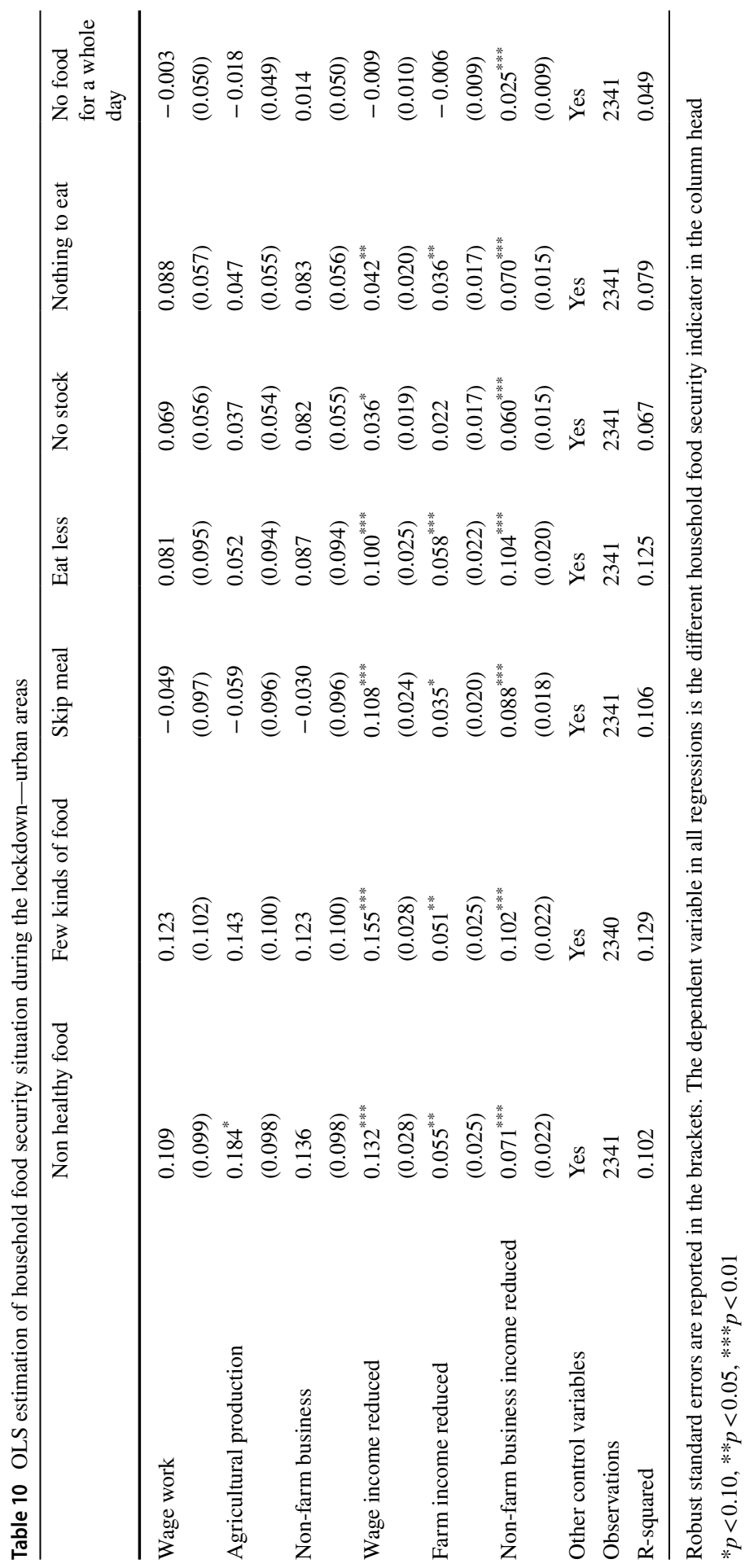




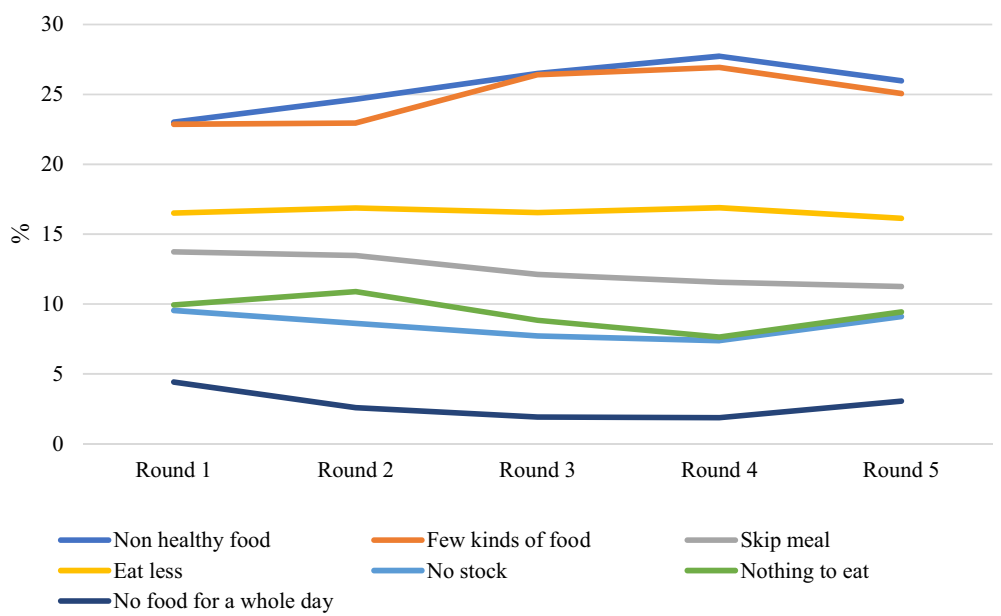

Fig. 1 Incidence of household food insecurity over time

them cope with shocks or possibly during off agricultural season when they do not have farm activities to undertake. In general, the respective results in Tables 9 and 10 also followed the same trend seen between Tables 7 and 8. Overall, the elevated levels of food insecurity especially in rural areas suggests that COVID-19 may have reversed some of the gains recorded in recent years in lifting millions of rural smallholder farming households - those who typically constitute the biggest proportion of the poor in the country-out of poverty. This would be consistent with the findings of Valensisi (2020) who shows that the COVID-19 pandemic may have pushed between 68 and 100 million people into poverty globally in 2020 .

\section{Incidence of Household Food Insecurity Over Time}

Figure 1 tracks the progression of households' food insecurity situation over the five rounds of data collection. The trends clearly show that up to the fourth round, there was a clear reduction in incidences of households that had no food stock, nothing to eat, no food for a whole, and/ or skipped a meal. On the other hand, there was also an increase in incidences of households that ate non healthy or fewer kinds of food. While still within the zone of food insecurity, it appears that households were able to transition from extreme to less extreme forms of food insecurity months after the lockdown started. We attribute these transitions to a stabilisation of their access to food over time. This may be because over the course of the lockdown, the government did provide exceptions to initial stringent rules which barred almost all businesses from operating. In this regard, the government published guidelines which detailed the standard operating procedures for many businesses to implement whilst in operation. This allowed many people to resume work and is likely, therefore, to have contributed to the reduction of incidences of extreme food insecurity over time. This trend generally echoes the findings of Ruan et al. (2021) who showed that following an initial lockdown induced spike, prices of wholesale vegetables eventually stabilised at their usual 
annual average after 11 weeks. Between the fourth and the fifth round, there was a reversal in the trends observed in the preceding four rounds. Other than being the peak of lean season in the country, this period also coincided with the peak of Uganda's 2021 national electoral season when lockdown rules were enforced stringently due to fears of large movement of people possibly contributing to spread of COVID-19. These two dynamics likely explain the changes in food insecurity in round five.

\section{Conclusion and Policy Suggestions}

In this paper we examined the impacts of COVID-19 lockdown induced income losses on household food security in Uganda. Our analysis shows that lockdown induced income losses significantly increased within households' incidences of eating less, non-healthy and few kinds of food, skipping a meal, having nothing to eat, or no food to eat for a whole day, and possession of no stock. We therefore conclude that lockdown induced income losses significantly increased the incidence of food insecurity among households by reducing their access to food. While income-based food access and its associated challenges generally tends to be a concern for urban households on account of their dependence on market-purchased food, our results show that the lockdowns exerted food access challenges across both urban and rural areas. However, our analysis also shows that there was a gradual recovery in the food security situation over the course of the lockdowns.

The main policy recommendations from these findings which may be useful in the future in preparing for similar shocks are threefold. First, for waged workers, there is need for the development of an all-inclusive employment insurance scheme that can provide protection to workers when unprecedented shocks such as the one occasioned by the pandemic occur. This will help to smoothen their income amidst uncertainty thus protecting their welfare. Secondly, for non-farm businesses, there is need to develop and deepen the financial markets to be able to provide credit to both large and small businesses including special products that can support businesses in the informal sector. Given that the government COVID-19 stimulus package was largely accessible to large businesses in the formal sector only, the government may also want to develop systems that can allow it to increase its support to the small businesses in the future. Thirdly, there is need for targeted investment in building the resilience capacity of particularly agricultural households in rural areas where over $70 \%$ of the population still lives. Addressing pre-existing inefficiencies in the production system may substantially enhance the food security resilience of particularly rural agricultural households to future epidemics. These inefficiencies can be addressed through, for example, enhanced investment in the increased use of improved inputs and the mechanisation of agricultural operations across the entire value chain of production from land preparation, weeding, harvesting, and post-harvest operations. This latter suggestion is supported by evidence from the work of Deininger and Okidi (2003), and Fan and Zhang (2008) on Uganda who show that investments in increasing the production and productivity of the poor provides the best avenue for poverty reduction and leads to improved food security outcomes. Additionally, as Abraham and Pingali (2017) have shown, growth in agriculture will offer great potential for reducing food insecurity. 


\section{Appendix}

See Tables 11, 12, 13, 14.

Table 11 Variable descriptions

\begin{tabular}{|c|c|}
\hline Variable & Description \\
\hline Female & Dummy $=1$ if household head is female and zero otherwise \\
\hline Age & Age in years of household head \\
\hline Married & Dummy $=1$ if household head is married and zero otherwise \\
\hline Household size & Number of ordinarily resident household members \\
\hline Number of household children & Number of ordinarily resident children in the household \\
\hline Rural & Dummy $=1$ if a household is located in a rural area and zero otherwise \\
\hline Urban & Dummy $=1$ if a household is located in an urban area and zero otherwise \\
\hline \multicolumn{2}{|l|}{ Region } \\
\hline Central & $\begin{array}{l}\text { Dummy }=1 \text { if a household is located in the Central region and zero } \\
\text { otherwise }\end{array}$ \\
\hline Eastern & $\begin{array}{l}\text { Dummy }=1 \text { if a household is located in the Eastern region and zero } \\
\text { otherwise }\end{array}$ \\
\hline Northern & $\begin{array}{l}\text { Dummy }=1 \text { if a household is located in the Northern region and zero } \\
\text { otherwise }\end{array}$ \\
\hline Western & $\begin{array}{l}\text { Dummy }=1 \text { if a household is located in the Western region and zero } \\
\text { otherwise }\end{array}$ \\
\hline \multicolumn{2}{|l|}{ Occupation } \\
\hline Wage work & $\begin{array}{l}\text { Dummy }=1 \text { if at least a household member engaged in wage work and } \\
\text { zero otherwise }\end{array}$ \\
\hline Agricultural production & $\begin{array}{l}\text { Dummy }=1 \text { if at least the household engaged in agricultural work and } \\
\text { zero otherwise }\end{array}$ \\
\hline Non-farm business & $\begin{array}{l}\text { Dummy }=1 \text { if at least the household engaged in non-farm business and } \\
\text { zero otherwise }\end{array}$ \\
\hline \multicolumn{2}{|l|}{ Income reduction } \\
\hline Wage work & $\begin{array}{l}\text { Dummy }=1 \text { if a household suffered a reduction in its wage work income } \\
\text { and zero otherwise }\end{array}$ \\
\hline Agricultural production & $\begin{array}{l}\text { Dummy }=1 \text { if a household suffered a reduction in its farm income and } \\
\text { zero otherwise }\end{array}$ \\
\hline Non-farm business & $\begin{array}{l}\text { Dummy }=1 \text { if a household suffered a reduction in its non-farm business } \\
\text { income and zero otherwise }\end{array}$ \\
\hline \multicolumn{2}{|l|}{ Food security } \\
\hline Non-healthy food & Dummy $=1$ if a household ate non-healthy food and zero otherwise \\
\hline Few kinds of food & Dummy $=1$ if a household ate few kinds of food and zero otherwise \\
\hline Skip meal & Dummy $=1$ if a household skipped meals and zero otherwise \\
\hline Eat less & Dummy $=1$ if a household ate less food and zero otherwise \\
\hline No stock & Dummy $=1$ if a household had no stock of food and zero otherwise \\
\hline Nothing to eat & Dummy $=1$ if a household had nothing to eat and zero otherwise \\
\hline No food for a whole day & Dummy $=1$ if a household had no food the whole day and zero otherwise \\
\hline
\end{tabular}


Table 12 Household food security status by wage income loss

\begin{tabular}{llllll}
\hline Indicator & All & $\begin{array}{l}\text { No wage } \\
\text { income loss }\end{array}$ & Wage income loss & Difference & SE \\
\hline Non healthy food & 0.474 & 0.448 & 0.631 & $-0.183 * * *$ & $(0.014)$ \\
Few kinds of food & 0.454 & 0.425 & 0.622 & $-0.197 * * *$ & $(0.013)$ \\
Skip meal & 0.211 & 0.190 & 0.338 & $-0.148 * * *$ & $(0.011)$ \\
Eat less & 0.278 & 0.253 & 0.427 & $-0.174 * * *$ & $(0.012)$ \\
No stock & 0.145 & 0.130 & 0.230 & $-0.100 * * *$ & $(0.010)$ \\
Nothing to eat & 0.153 & 0.139 & 0.236 & $-0.097 * * *$ & $(0.010)$ \\
No food for a whole day & 0.055 & 0.051 & 0.080 & $-0.029 * * *$ & $(0.006)$ \\
Observations & 10,822 & & & & \\
\hline
\end{tabular}

Source Based on Authors calculations (HFPS Round 1, 2, 3, 4 \& 5)

$* p<0.05, * * p<0.01, * * * p<0.001$

Table 13 Household food security status by farm income loss

\begin{tabular}{llllll}
\hline Indicator & All & $\begin{array}{l}\text { No farm } \\
\text { income loss }\end{array}$ & Farm income loss & Difference & SE \\
\hline Non healthy food & 0.47 & 0.424 & 0.576 & $-0.152^{* * *}$ & $(0.010)$ \\
Few kinds of food & 0.45 & 0.402 & 0.56 & $-0.158^{* * *}$ & $(0.010)$ \\
Skip meal & 0.21 & 0.170 & 0.295 & $-0.125^{* * *}$ & $(0.008)$ \\
Eat less & 0.28 & 0.226 & 0.383 & $-0.157 * * *$ & $(0.009)$ \\
No stock & 0.15 & 0.117 & 0.2 & $-0.083 * * *$ & $(0.007)$ \\
Nothing to eat & 0.15 & 0.119 & 0.222 & $-0.103 * * *$ & $(0.007)$ \\
No food for a whole day & 0.06 & 0.048 & 0.071 & $-0.023 * * *$ & $(0.005)$ \\
Observations & 10,822 & & & & \\
\hline
\end{tabular}

Source: Based on Authors calculations (HFPS Round 1, 2, 3, 4 \& 5)

${ }^{*} p<0.05, * * p<0.01, * * * p<0.001$

Table 14 Household food security status by non-farm income loss

\begin{tabular}{lllllr}
\hline Indicator & All & $\begin{array}{l}\text { No non-farm } \\
\text { income loss }\end{array}$ & $\begin{array}{l}\text { Non-farm } \\
\text { income loss }\end{array}$ & Difference & SE \\
\hline Non healthy food & 0.474 & 0.454 & 0.53 & $-0.076^{* * *}$ & $(0.011)$ \\
Few kinds of food & 0.454 & 0.425 & 0.534 & $-0.109^{* * *}$ & $(0.011)$ \\
Skip meal & 0.211 & 0.18 & 0.297 & $-0.117^{* * *}$ & $(0.009)$ \\
Eat less & 0.278 & 0.241 & 0.378 & $-0.136^{* * *}$ & $(0.010)$ \\
No stock & 0.145 & 0.125 & 0.198 & $-0.073^{* * *}$ & $(0.008)$ \\
Nothing to eat & 0.153 & 0.13 & 0.214 & $-0.084^{* * *}$ & $(0.008)$ \\
No food for a whole day & 0.055 & 0.051 & 0.067 & $-0.016^{* *}$ & $(0.005)$ \\
Observations & 10,822 & & & & \\
\hline
\end{tabular}

Source: Based on Authors calculations (HFPS Round 1, 2, 3, 4 \& 5)

$* p<0.05, * * p<0.01, * * * p<0.001$ 


\section{Declarations}

Conflict of interest The corresponding author states that there is no conflict of interest.

\section{References}

Abraham, M., and P. Pingali. 2017. Transforming smallholder agriculture to achieve the SDGs. In The role of smallholder farms in food and nutrition security, ed. S. Gomez y Paloma, et al. Cham: Springer.

Akter, S., and S.A. Basher. 2014. The impacts of food price and income shocks on household food security and economic well-being: Evidence from rural Bangladesh. Global Environmental Change 25: 150-162.

Béné, C. 2020. Resilience of local food systems and links to food security-A review of some important concepts in the context of COVID-19 and other shocks. Food Security 12: 1-18.

Ceballos, F., S. Kannan, and B. Kramer. 2020. Impacts of a national lockdown on smallholder farmers' income and food security: Empirical evidence from two states in India. World Development 136: 105069.

Deininger, K., and J. Okidi. 2003. Growth and poverty reduction in Uganda, 1999-2000: Panel data evidence. Development Policy Review 21 (4): 481-509.

Fan, S., and X. Zhang. 2008. Public expenditure, growth and poverty reduction in rural Uganda. African Development Review 20 (3): 466-496.

FAO. 2021. FAO food price index. http://www.fao.org/worldfoodsituation/foodpricesindex/en/ Accessed 11th April 2021.

Farrell, P., A.M. Thow, J.T. Wate, N. Nonga, P. Vatucawaqa, T. Brewer, and N.L. Andrew. 2020. COVID19 and Pacific food system resilience: Opportunities to build a robust response. Food Security 12 (4): 783-791

Foeken, D.W., and S.O. Owuor. 2008. Farming as a livelihood source for the urban poor of Nakuru, Kenya. Geoforum 39 (6): 1978-1990.

Gupta, A., H. Zhu, M.K. Doan, A. Michuda, and B. Majumder. 2020. Economic impacts of the COVID19 lockdown in a remittance-dependent region. American Journal of Agricultural Economics 103: 466-485.

Heck, S., H. Campos, I. Barker, J.J. Okello, A. Baral, E. Boy, and E. Birol. 2020. Resilient agri-food systems for nutrition amidst COVID-19: Evidence and lessons from food-based approaches to overcome micronutrient deficiency and rebuild livelihoods after crises. Food Security 12 (4): 823-830.

Hirvonen, K., A. de Brauw, and G.T. Abate. 2021. Food consumption and food security during the COVID-19 pandemic in addis ababa. American Journal of Agricultural Economics. https://doi.org/ 10.1111/ajae.12206.

Huss, M., M. Brander, M. Kassie, U. Ehlert, and T. Bernauer. 2020. Improved storage mitigates vulnerability to food-supply shocks in smallholder agriculture during the COVID-19 pandemic. Global Food Security 28: 100468.

Initiatives for Social and Economic Rights. 2021. Uganda's COVID-19 economic stimulus package: will it deliver? ISER, Kampala, Uganda. Available at https://iser-uganda.org/images/downloads/Ugand as_COVID-19_Economic_Stimulus_Package-Will_it_deliver.pdf

International Labour Organization. 2020. ILOSTAT database. https://ilostat.ilo.org/data/ Accessed 13 January 2021.

International Labour Organization. 2021. ILO Monitor: COVID-19 and the world of work. Seventh edition. Available at https://www.ilo.org/wcmsp5/groups/public/@dgreports/@dcomm/documents/ briefingnote/wcms_767028.pdf Accessed 7 June 2021.

Isabirye, N., and B. Musasizi. 2020. COVID-19 relief food distribution: Impact and lessons for Uganda. The Pan African Medical Journal 35 (142): 2.

Kansiime, M.K., J.A. Tambo, I. Mugambi, M. Bundi, A. Kara, and C. Owuor. 2021. COVID-19 implications on household income and food security in Kenya and Uganda: Findings from a rapid assessment. World Development 137: 105199. 
Laborde, D., W. Martin, J. Swinnen, and R. Vos. 2020. COVID-19 risks to global food security. Science 369 (6503): 500-502.

Leroy, J.L., M. Ruel, E.A. Frongillo, J. Harris, and T.J. Ballard. 2015. Measuring the food access dimension of food security: A critical review and mapping of indicators. Food and Nutrition Bulletin 36 (2): 167-195.

Mahmud, M., and E. Riley. 2020. Household response to an extreme shock: Evidence on the immediate impact of the Covid-19 lockdown on economic outcomes and well-being in rural Uganda. World Development 140: 105318.

Maxwell, D.G. 1995. Alternative food security strategy: A household analysis of urban agriculture in Kampala. World Development 23 (10): 1669-1681.

Maxwell, D.G. 1996. Measuring food insecurity: The frequency and severity of "coping strategies". Food Policy 21 (3): 291-303.

Mkwambisi, D.D., E.D. Fraser, and A.J. Dougill. 2011. Urban agriculture and poverty reduction: Evaluating how food production in cities contributes to food security, employment and income in Malawi. Journal of International Development 23 (2): 181-203.

Nagler, P. and W. Naude. 2014. Non-farm enterprises in rural Africa: New empirical evidence. World Bank Policy Research Working Paper (7066).

Noreen, E. 1988. An empirical comparison of probit and OLS regression hypothesis tests. Journal of Accounting Research 1: 119-133.

Peel, M.J., M.M. Goode, and L.A. Moutinho. 1998. Estimating consumer satisfaction: OLS versus ordered probability models. International Journal of Commerce and Management 8: 75-93.

Rahman, H.Z., I. Matin, N. Banks, and D. Hulme. 2021. Finding out fast about the impact of covid-19: The need for policy-relevant methodological innovation. World Development 140: 105380.

Ruan, J., Q. Cai, and S. Jin. 2021. Impact of COVID-19 and nationwide lockdowns on vegetable prices: evidence from wholesale markets in China. American Journal of Agricultural Economics. https:// doi.org/10.1111/ajae.12211.

Simler, K. R. 2010. The short-term impact of higher food prices on poverty in Uganda. World Bank Policy Research Working Paper, (5210).

Shiva, M., and H. Molana. 2021. The luxury of lockdown. The European Journal of Development Research 34: 1-21.

Stoop, N., S. Desbureaux, A. Kaota, E. Lunanga, and M. Verpoorten. 2021. Covid-19 vs. Ebola: Impact on households and small businesses in North Kivu. Democratic Republic of Congo. World Development 140: 105352.

Uganda Bureau of Statistics. 2019. Poverty Maps of Uganda - Mapping the Spatial Distribution of Poor Households and Child Poverty Based on Data from the 2016/17 Uganda National Household Survey and the 2014 National Housing and Population Census. Technical Report. UBOS, Kampala https:// www.ubos.org/wp-content/uploads/publications/02_2020Poverty_Map_report_Oct_2019.pdf.

Uganda Bureau of Statistics. 2020. Uganda High-Frequency Phone Survey on COVID-19 (HFPS) 20202021. Ref. UGA_2020_HFPS_v04_M. Dataset downloaded from https://microdata.worldbank.org/ index.php/catalog/3765 accessed 30 May 2021.

Valensisi, G. 2020. COVID-19 and global poverty: Are LDCs being left behind? The European Journal of Development Research 32 (5): 1535-1557.

Verpoorten, M., A. Arora, N. Stoop, and J. Swinnen. 2013. Self-reported food insecurity in Africa during the food price crisis. Food Policy 39: 51-63.

World Bank. 2021. Uganda economic update 17th edition: From crisis to green resilient growth-investing in sustainable land management and climate smart agriculture. Washington, D.C.: World Bank Group.

World Bank. 2020. World Development Indicators. https://data.worldbank.org/indicator/SP.RUR.TOTL. ZS ?locations=UG Accessed 11 January 2021.

World Food Summit. 1996. Rome declaration on world food security. Rome: FAO.

Yuan, Z., Y. Xiao, Z. Dai, J. Huang, Z. Zhang, and Y. Chen. 2020. Modelling the effects of Wuhan's lockdown during COVID-19, China. Bulletin of the World Health Organization 98 (7): 484-494.

Zidouemba, P.R., S.R. Kinda, and I.M. Ouedraogo. 2020. Could covid-19 worsen food insecurity in Burkina Faso? The European Journal of Development Research 32 (5): 1379-1401.

Publisher's Note Springer Nature remains neutral with regard to jurisdictional claims in published maps and institutional affiliations. 